\title{
ガスタービンの操業経験*
}

北越製紙株式会社 市川工場施設課 田 村 和 則

\section{Operating Experience of Gas Turbine Power Plant}

Kazunori Tamura

Ichikawa Mill, HOKUETU Paper Mills., Ltd.

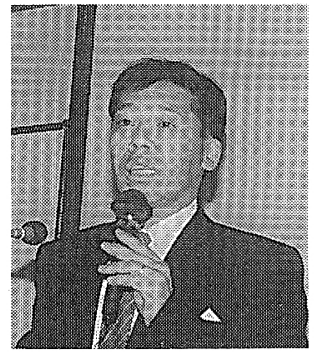

In 1995, a gas turbine power plant was introduced into Ichikawa Mill in HOKUETU PAPER Ltd. in order to change the existing boiler and reduce energy cost. These co-generation facilities enabled us to obtain an independent electric production source and transmit surplus electricity for TOKYO ELECTORIC POWER Co. We changed over from oil ( $\mathrm{S}=$ $2.6 \%$ ) to city gas for fuel, so that environmental pollution would not increase in the future. In addition, by utilizing an existing steam turbine plant efficiently, the mill energy cost could be lowered successfully. After initiating the operation of this plant, several problems were confronted. Our experiences accumulated through this operation over about 3 years are described in this paper.

\section{1.はじめに}

当社市川工場は，洋紙と白板紙の 2 本立てであるが， 古紙原料が $80 \%$ 以上の原料構成になっており，地球 環境の保全に資源のリサイクルに貢献できる都会地工 場として存在価値のある工場を目指している。

当工場では, 平成 7 年に発電用重油ボイラーの老朽 更新に合わせて, 高効率なガスタービンコージェネ発 電設備を導入した。運転開始以来約 3 年を経過したが, これまでの操業実績について報告する。

\section{2. 導入の背景}

既設ボイラーは, 昭和 39 年に運転開始以来約 30 年 を経過し, 運転時間も25万時間を超え, 老朽化が進 んできていた。对応策として既設の改修や重油ボイラ 一の更新等を検討したが，以下の条件のもとで新なな

*第 3 回省エネルギーセミナー講演
発電設備の新設について検討を行った。

・都会地工場として将来動向を踏まえた環境対策が 可能なこと。

・限られたスペースに設置できること。

・操業において現有人員で運転できること。

- 自家発電比率 $100 \%$, 電力会社への逆潮流 (売 電）が可能なこと。

・投資採算に見合うこと。

多方面から検討の結果, 前提条件を満足する設備と して, 排熱ボイラー付きがスタービン発電設備が現状 の問題点をクリアする一番有利な投資であるとの結論 を得た。

\section{3. ガスタービンコージェネ発電設備の概要}

この結論のもとに, 工場の操業条件を加味してがス タービン発電設備の仕様を決定した。表 1 にガスター ビン発電設備主要の仕様, 図 1 に設備フローとヒート バランス, 図 2 に設備配置図を示す。 
表 1 主要機器仕様

\begin{tabular}{|c|c|c|c|c|}
\hline 機器名称 & & 様 & 備 & 考 \\
\hline ガスタービン & $\begin{array}{l}\text { 形 式 } \\
\text { 出 力 } \\
\text { 回 転 数 } \\
\text { 燃 料 } \\
\text { NOx 低減 }\end{array}$ & $\begin{array}{l}\text { 単純開放サイクル一軸型；MF-111 B } \\
17,000 \mathrm{~kW} \\
\left.\quad \text { (大気温度 } \quad 15^{\circ} \mathrm{C}\right) \\
9,660 \mathrm{rpm} \\
\text { 都市ガス } \\
\text { 蒸気噴射 } \\
\text { NH } 3 \text { 接触還元式脱硝装置 }\end{array}$ & 新 & 設 \\
\hline 排熱ボイラー & $\begin{array}{ll}\text { 圧力 } & \text { (最高) } \\
\text { 温 度 } \\
\text { 燃 料 }\end{array}$ & $\begin{array}{lcc}\text { 複圧自然循環型 } & \text { ダクトバーナー付 } \\
60 \mathrm{~T} / \mathrm{H} & & \\
& \text { (単独運転時 } & 50 \mathrm{~T} / \mathrm{H}) \\
& \text { 高圧部 } & \text { 低圧部 } \\
& 65(75) & 0.45(4.8) \\
\mathrm{kg} / \mathrm{cm}^{2} \mathrm{G} & 65 & 200 \text { (最高) } \\
{ }^{\circ} \mathrm{C} & 458 & \\
\text { 都市ガス } & (13 \mathrm{~A})\end{array}$ & 新 & 設 \\
\hline 蒸気タービン & $\begin{array}{ll}\text { 形 式 } \\
\text { 出 力 } \\
\\
\text { 圧 力 } \\
\text { 温 度 }\end{array}$ & 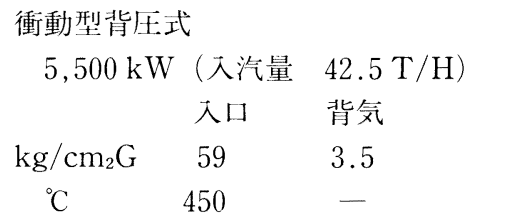 & 既 & 設 \\
\hline
\end{tabular}

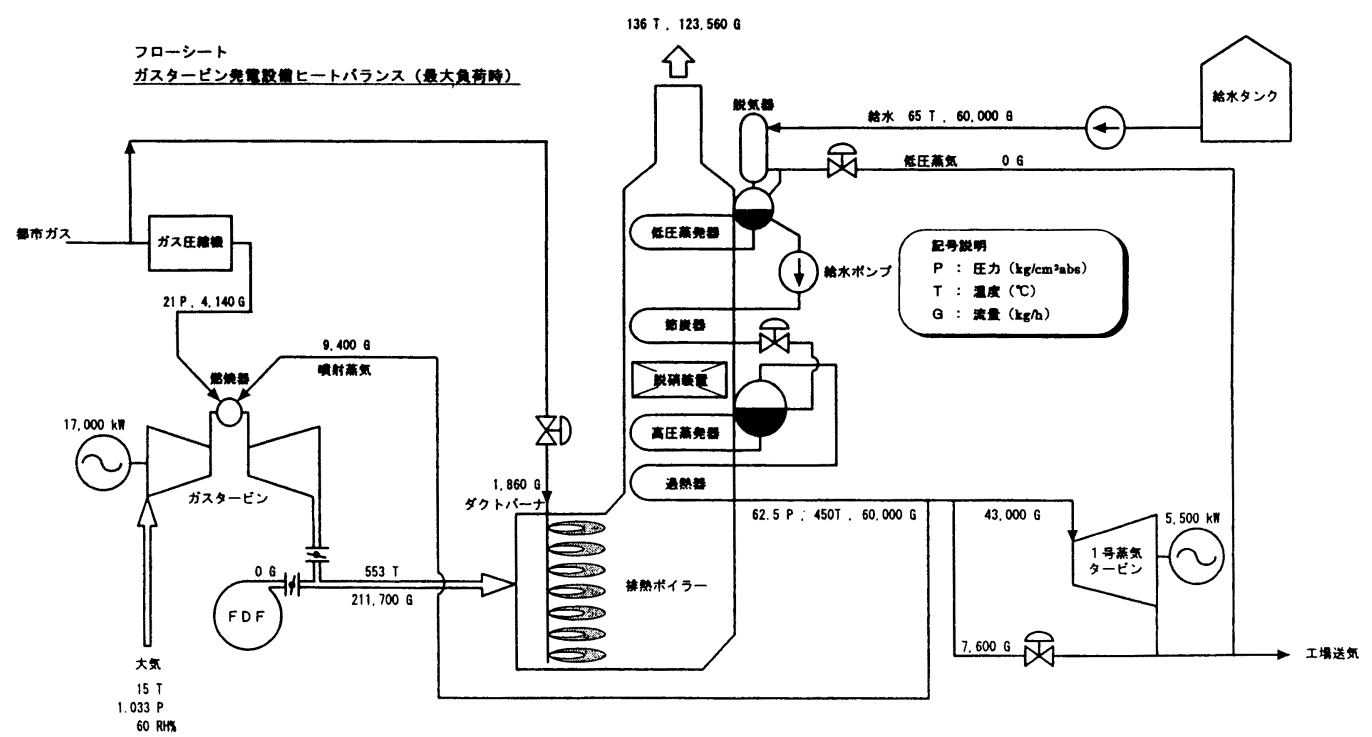

図 1 フローシートとヒートバランス 

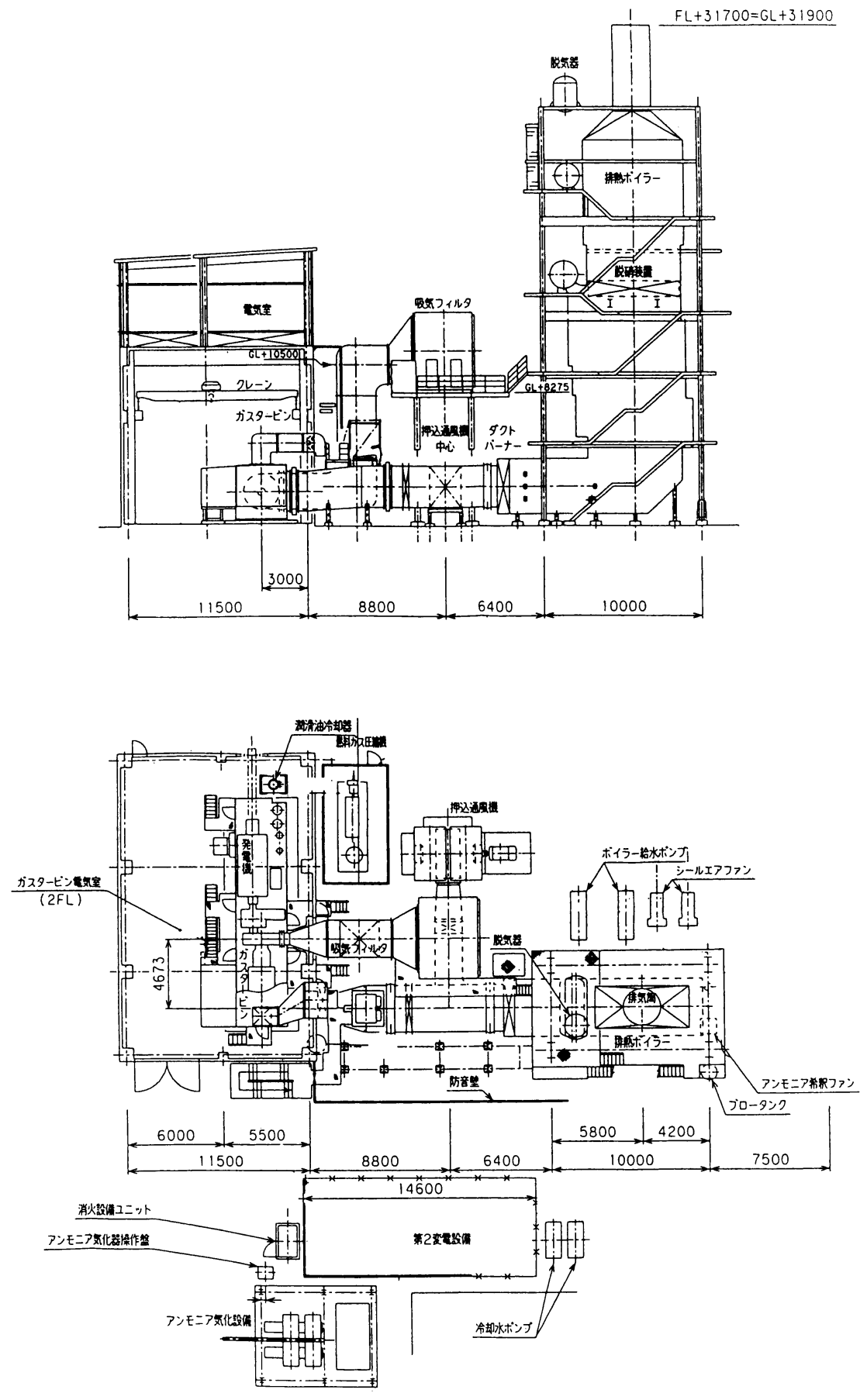

図 2 設備配置困 


\section{4. 設備の特徵}

（1）ガスタービンと助燃用ダクトバーナーを有する 排熱ボイラーを組み合わせることで，総合熱効率を $80 \%$ の高効率まで向上させた。

（2）排熱ボイラーの蒸気条件は，助燃により既設蒸 䒝タービンの仕様に適合させることで, ガスタービン の負荷変動によっても蒸気夕ービンの発電効率が下が らないようにした。

（3）ガスタービン定検時でも，排熱ボイラーの単独 運転を行えるように強圧通風機を併設している。これ によって，ガスタービン停止期間でも既設蒸気夕ービ ンでの発電が可能となり, 購入電力の減少が四られる。

(4) 空気压縮機の污れに起因する発電出力の低下を 防止する対策として, 建設当初から 3 段式吸気フィル ターを採用した。

（5）環境対策として，大気関係では燃料としてガス タービンと排熱ボイラーは都市ガスを使用している。 $\mathrm{NOx}$ の削減は，ガスタービンでの蒸気噴射及び排熱 ボイラーでのアンモニア接触還元方式の脱硝設備で対 忍している。表 2 に大気関係の規制值を示す。運転の 方式で 3 通りとなっている。

また，ガスタービンを RC 建屋内に設置し，吸排気 ダクトの防音対策や防音壁で騒音対策にも万全を期し
た。

\section{5. 運 転 実 績}

平成 7 年 8 月より営業運転に入り，平成 10 年 4 月 に第 3 回目の開放点検を実施した。これまでの運転実 績及び開放点検の結果について述べる。

\section{1 起動 - 停止特性}

ガスタービン本体の起動・停止は全て自動化されて おり, 中操 DCS からの指令で行われる。起動から併列, 初期負荷取り迄の所要時間は約 15 分である。一方, 排熱ボイラーも昇圧に応じた弁操作（ドレン切り，工 ア抜き等）は全て自動で行われる。設備全体が定格負 荷になる迄の所要時間は，45～60 分である。停止も 同様に発電負荷減, 解列, クーリング, 停止, 夕一二 ング迄全て自動で行われる。停止指令からターニング 起動までの所要時間は約 20 分である。

ガスタービンの起動及び停止での機器動作の夕イム スケジュールを図 3 に示す。

\section{2 ガスタービンの運用}

運用面での特徵は, 工場需要電力に加えて東京電力 株式会社への売電実施であり，この総電力量をガス夕 一ビンと蒸気タービンとで全て供給していることであ る。電力変動分はガスタービンの負荷で調整し, 吸収 している。売電量は次の 3 通りであり, 表 3 に示す。

表 2 大気関係規制值

\begin{tabular}{l|c|c|c}
\hline & コンバインド & ボイラー単独 & ガスタービン単独 \\
\hline $\mathrm{NOx}$ & $100 \mathrm{ppm}$ & $100 \mathrm{ppm}$ & $20 \mathrm{ppm}$ \\
ばいじん & $0.05 \mathrm{~g} / \mathrm{Nm}^{3}$ & $0.05 \mathrm{~g} / \mathrm{Nm}^{3}$ & $0.05 \mathrm{~g} / \mathrm{Nm}^{3}$ \\
換算 $\mathrm{O}_{2} \%$ & $5 \%$ & $5 \%$ & $16 \%$ \\
\hline
\end{tabular}

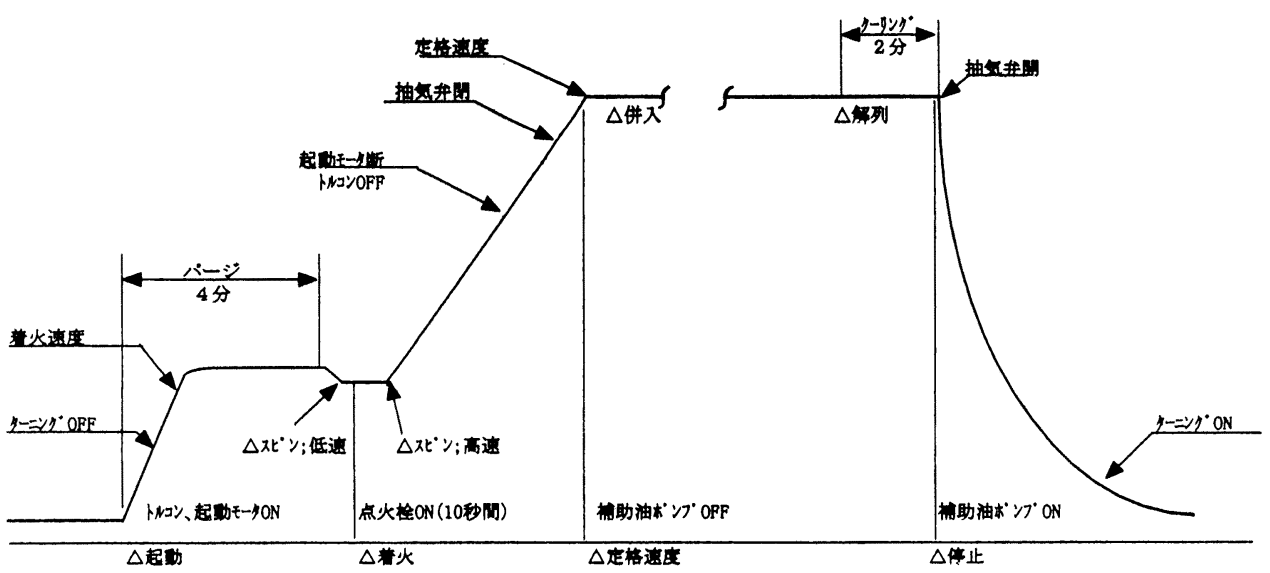

図 3 起動及び停止での夕イムスケジュール 
表 3 送電パターン

\begin{tabular}{|c|c|}
\hline 送電パターン & 売電比率 \\
\hline 平日 $8: 00 \sim 22: 00$ & $60 \%$ \\
\hline 平日 $22: 00 \sim 8: 00$ & $35 \%$ \\
\hline 休日 $8: 00 \sim 8: 00$ & $35 \%$ \\
\hline
\end{tabular}

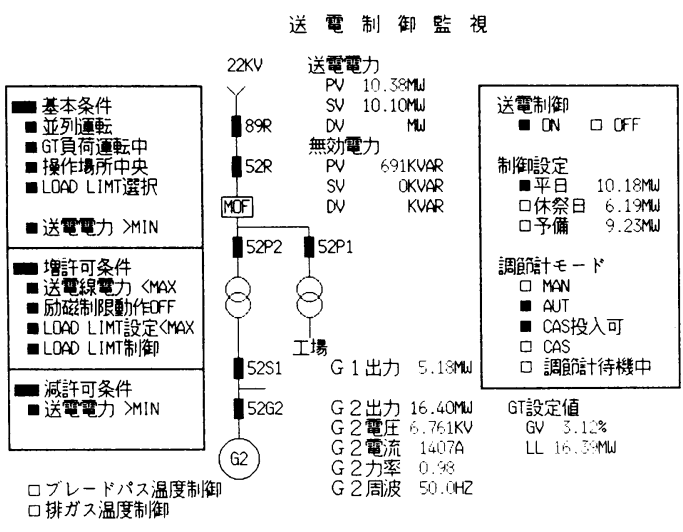

図 4 送電制御の制御監視画面

ガスタービンは通常, 昼夜・休日で $25 \%$ の出力差で 運用されている。送電制御の DCS 画面を図 4 に示す。

\section{3 排熱ボイラーの単独運転}

排熱ボイラー単独移行でのボイラー運転状況を図 5 に示す。ガスタービンの定検停止時の切替え, 緊急卜 リップ時での単独運転移行や, 電力面での売電から買 電への移行についても支障はなく運転操業対応が可能 となっている。

\section{4 ガスタービンの出力低下}

（1）ガスタービンの出力低下をきたす大きな要因と して a）外気温度の上昇

b）空気圧縮機污れによる圧縮機効率の低下が挙 げられる。

（2）a）に対しては，ガスタービン車室に蒸気を噴 射して出力をアップさせることができる。これにより， 夏場の外気温度でも出力低下は発生していない。

（3）b）に対しては，大気中の污れを吸い込まない ように, 当初から 3 段式フィルターを設置している。 フィルターの効果は発揮されて, 出力低下は発生しな かったが, 反面 2 段目のフィルタ一使用寿命が 3 ケ月 弱と短いことが運転開始とともに問題となった。使用 寿命はフィルタ一差圧で管理しているが，その推移を 図 6 に示す。ガラス繊維を使用して濾材面積を多く織 り込んだ構造の他社品（日本無機製）に2，3段フィ ルターを切替えた。寿命は 1 年間超となりコスト的に も改善された。

（4）平成 5 年，新潟工場に同機種ガスタービンを導 人しているが，フィルターを設置しておらず，この効 果をフィードバックした。フィルター設置後は, 出力 低下はなく洗浄作業も実施していない。その效果を门 縮機効率の推移として図 7 に示す。

\section{5 日常保全と開放点検結果}

（1）日常保全については，通常行われている設備の 巡視点検以外に特別なものはなく, 通常運転時はノ一 メンテナンス設備である。

(2) 定検を含む開放点検を運転開始から平成 10 年 5 月まで 3 回実施している。高温部品類の補修状洗を 表 4 に示す。

高温部品類の損傷程度は使用燃料や入口ガス温度に よって大きく左右される。当工場での主な取替え要因 は,コーティング剝離・冷却穴詰まり焼損・減肉等で あった。
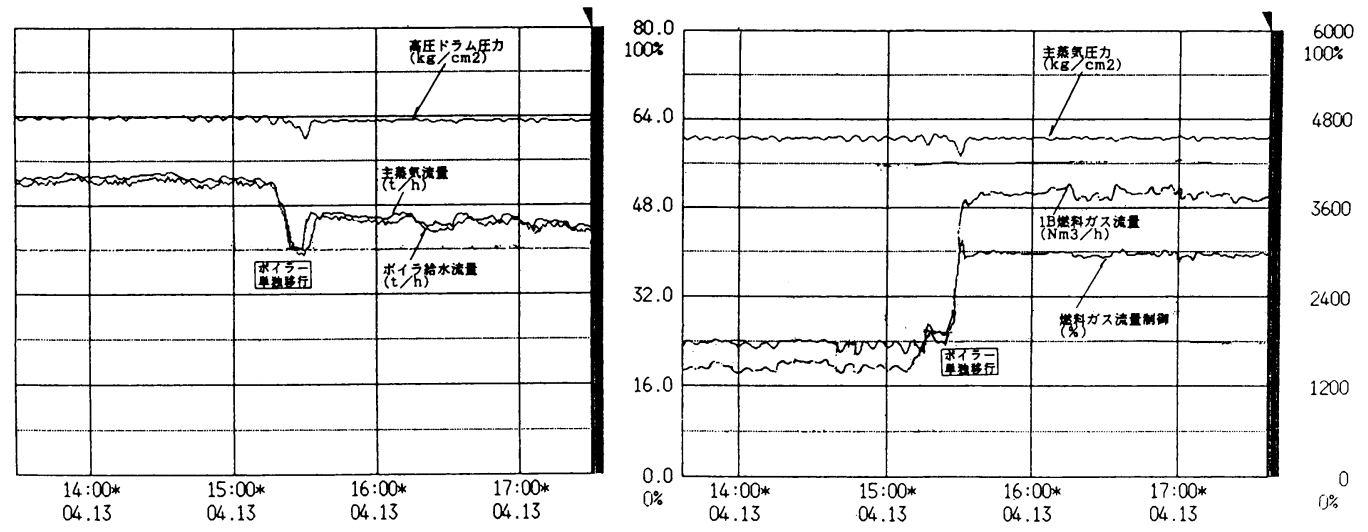

図 5 ボイラー単独運転移行での状況 


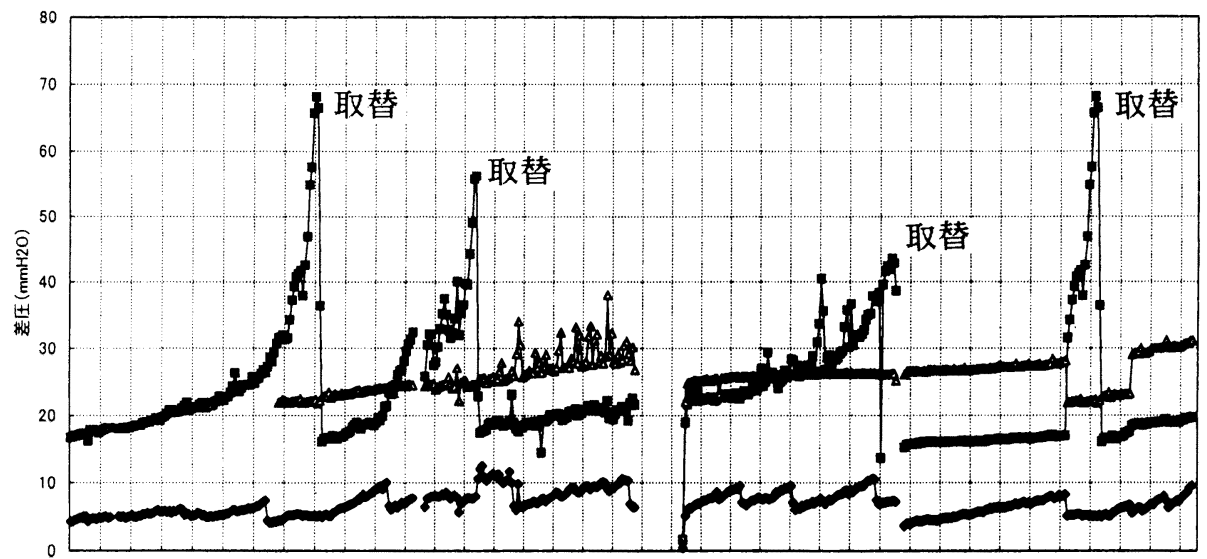

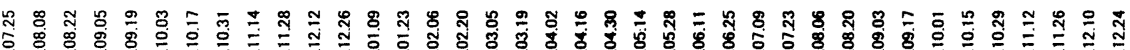



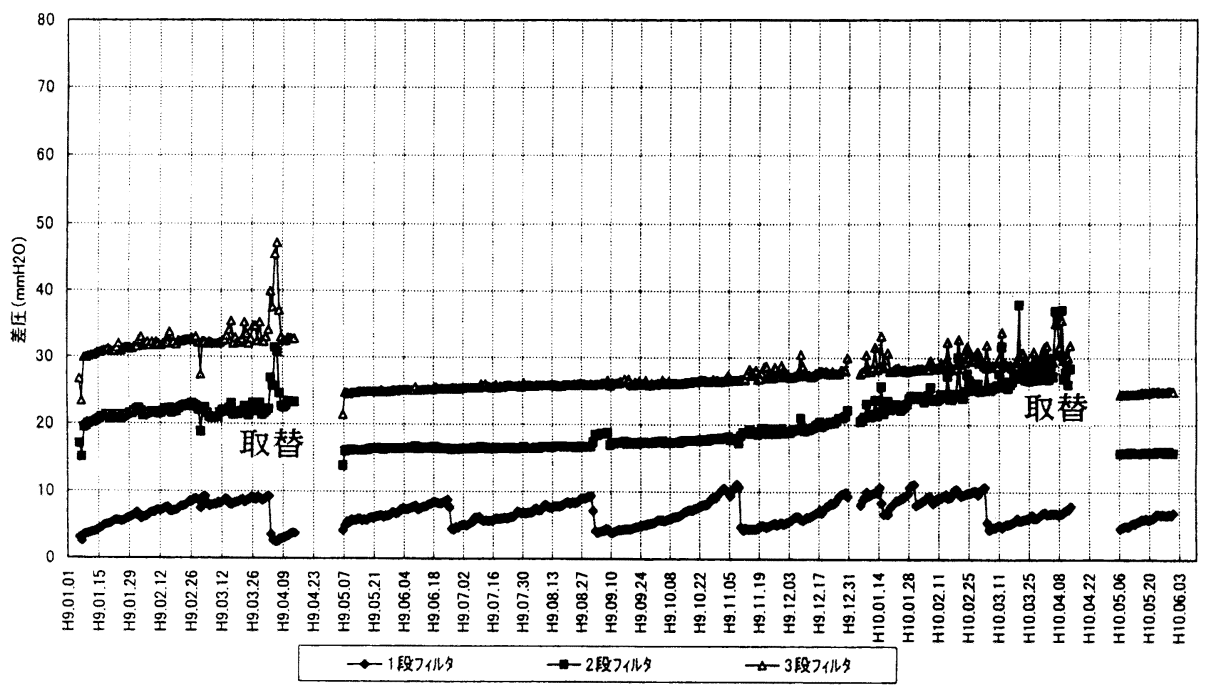

図 6 フィルター差厈の推移

表 4 高温部品類の補修状洗

\begin{tabular}{|c|c|c|c|c|c|c|}
\hline & & $\begin{array}{l}\text { 数 } \\
\text { 量 }\end{array}$ & $\begin{array}{c}\mathrm{H} 8 \text { 年 } \\
5,989 \mathrm{Hr}\end{array}$ & $\begin{array}{c}\text { H } 9 \text { 年 } \\
13,978 \mathrm{Hr}\end{array}$ & $\begin{array}{c}\mathrm{H} 10 \text { 年 } \\
22,011 \mathrm{Hr}\end{array}$ & $\begin{array}{c}\text { 予測寿命 } \\
\mathrm{Hr}\end{array}$ \\
\hline \multicolumn{2}{|c|}{ 燃焼器 内筒 } & 8 & 継続使用 & 継続使用 & 継続使用 & 25,000 \\
\hline \multicolumn{2}{|c|}{ 燃焼器 尾筒 } & 8 & 継続使用 & 再コーティング & 5 個取替 & 25,000 \\
\hline \multirow[t]{3}{*}{ 夕ービン動翼 } & $\# 1$ & 68 & 継続使用 & 1 枚取替 & 4 枚取替 & 30,000 \\
\hline & $\# 2$ & 64 & 継続使用 & 継続使用 & 継続使用 & 50,000 \\
\hline & $\# 3$ & 60 & 継続使用 & 継続使用 & 継続使用 & 100,000 \\
\hline \multirow[t]{3}{*}{ 夕ービン静翼 } & $\# 1$ & 44 & 1 枚取替 & 6 枚取替 & 6 枚取替 & 30,000 \\
\hline & $\# 2$ & 22 & 継続使用 & 継続使用 & 継続使用 & 40,000 \\
\hline & $\# 3$ & 12 & 継続使用 & 継続使用 & 継続使用 & 100,000 \\
\hline
\end{tabular}




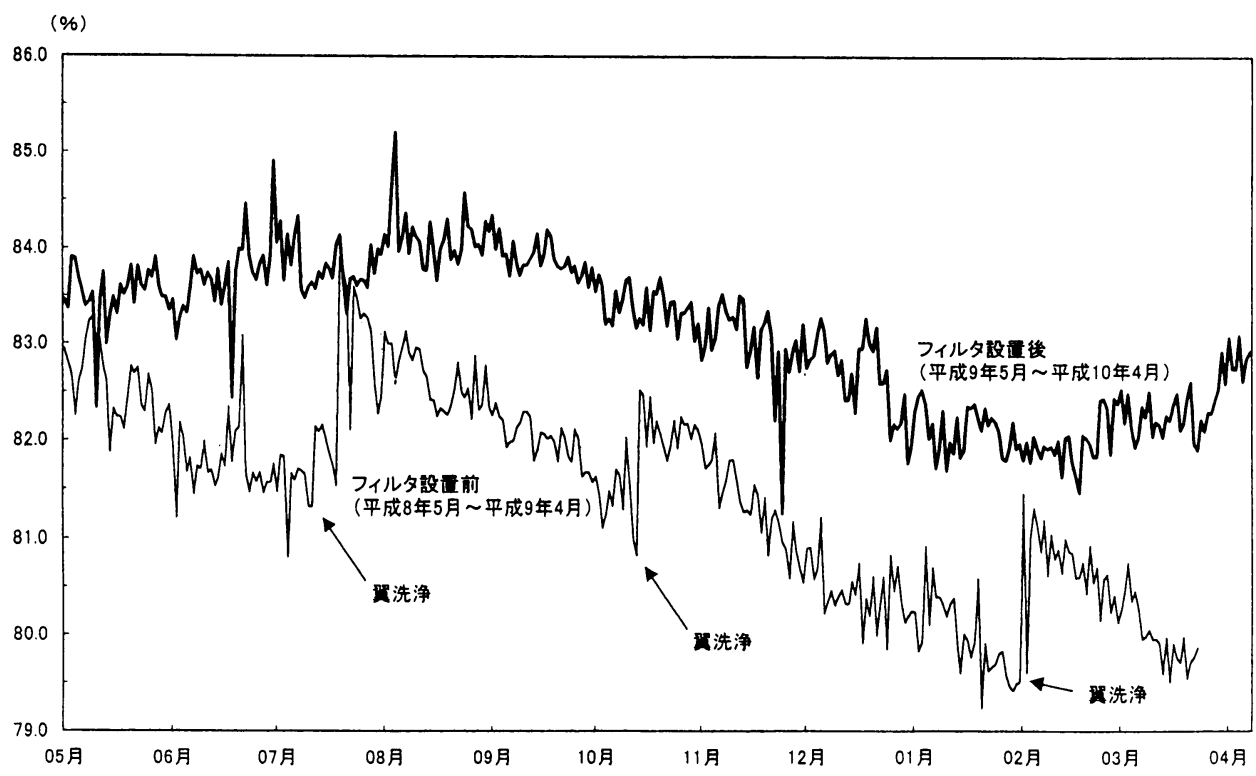

図 7 圧縮機効率の推移 (新潟工場)

\section{6 効果}

ガスタービンを設置したことにより，平成 7 年後期 から自家発電比率は図 8 に示すように設置前の $50 \%$ 弱からほぼ $100 \%$ となった。当初の計画どおり購入電 力の削減と売電の実施により, 収益改善に奇与してい る。

\section{6. 今後の課題}

\section{（1）高温部品の寿命について}

高温部品は非常に高価であり，入口ガス温度によっ て指数関数的に寿命が変わる。入口ガス温度を下げる ことは発電出力を低下させることであり，この損失と 部品コストとを考虑した最適経済性の運転管理をめざ

\section{している。}

高温部品類の履歴をもとに, 寿命を把握して使い切 るための実績データを集積してゆく必要がある。

(2) 定期及び開放検査の費用について

従来の蒸気夕ービンに比べて費用は高額であり, 走 検日数も24 日前後を要する。同機種を持つ新潟丁場 との部品類の共有化を行い, 定検日数の短緶化及び予 備品費用の圧縮を四り，総コストの削減を進めてゆく。

(3) 制御装置, 計装機器類の信頼性について

制御方法のほとんどがコンピュータによって, 起動 停止制御・運転制御をされており一個の計装部品不这 や䛊動作により，ガスタービンは瞬時に停止となる。 安定運転には, コンピュータや周辺機器の信頼性问上.

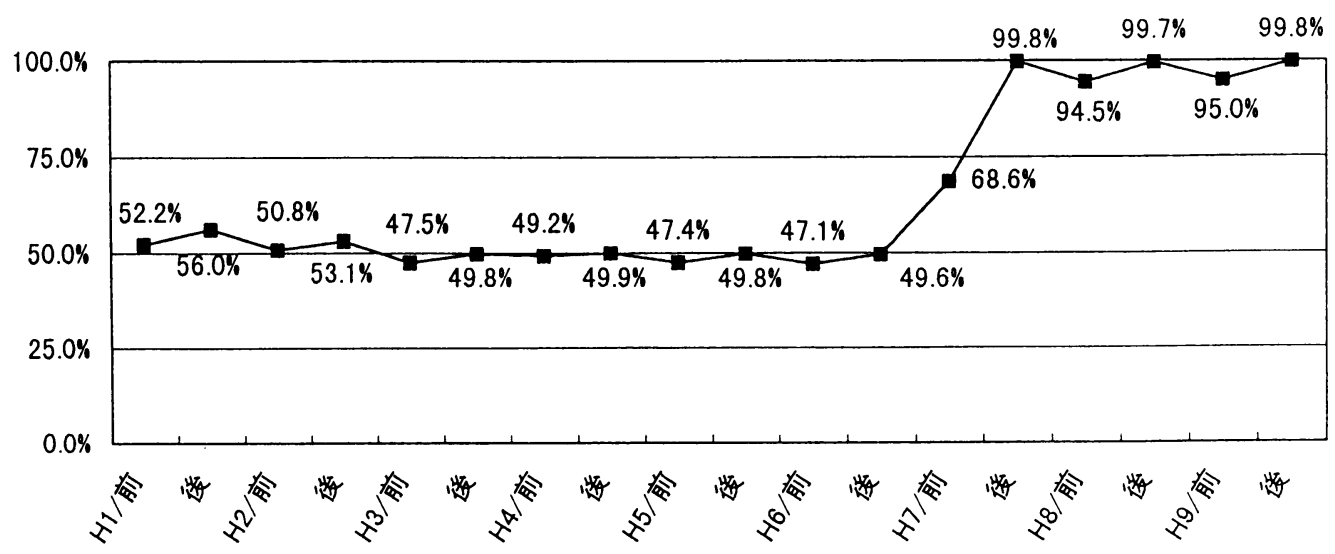

図 8 自家発電比率の推移 
が不叮欠であり, 計装機器類の点検保守も重要な対策 である。

\section{7. おわりに}

ガスタービンコージェネ発電設備の導入から 3 年余 の連転実績を述べてきたが, 発電用としての歴史も新
しく, 運転実績も従来の汽力発電に比べると少ないた め, 取り組んでゆく課題は多い。今後とも更に運転デ 一夕の蓄積に努めるとともに, 最適経済性の運転方案 の見直し, 操業技術, 保全技術の向上による安全性と 信頼性の確保を図っていきたい。 